\title{
Karyotypic Studies in Twenty-seven Species of Aphids \\ (Homoptera: Aphididae) from India
}

\author{
A. R. Khuda-Bukhsh and I. Kar \\ Department of Zoology, University of Kalyani, Kalyani-741 235, West Bengal, India
}

Accepted November 17, 1989

Out of over 4000 species of aphids taxonomically recorded throughout the world (Dixon 1985), some 735 species have so far been cytologically investigated (Kuznetsova and Shaposhnikov 1973, Kurl 1986, Khuda-Bukhsh and Kar 1987, Khuda-Bukhsh and Basu 1987, etc.). In India, the chromosomes of 167 species have so far been reported (Kar et al. 1990) out of over 750 species of aphids taxonomically recorded from this country (Ghosh 1975, Sarkar and Raychaudhuri 1985). Therefore, the present work was primarily undertaken with the objective of extending the chromosome data in this group of tiny pest insects.

The present communication deals with the diploid number, mitotic behaviour and morphometric data of chromosomes on embryos of 27 species of aphids, of which 18 species (marked with asterisk in Table 1) had not been cytologically investigated earlier.

\section{Materials and methods}

Apterous viviparous female specimens of 27 species of aphids were collected from different regions of India, the majority from the North-Eastern part (Table 1). Slides for chromosomal studies were prepared from tiny embryos as per the technique described earlier (KhudaBukhsh and Pal 1984, 1985). The diploid number in each species was determined from at least 50 well-spread metaphase complements. The chromosomes of more or less identical lengths were matched as homologous pairs. The relative percentage lengths $\left(R_{L}\right)$ of each pair in the complement were obtained from the mean values of 10 complements (Table 2) and the idiograms prepared on the basis of their $R_{L}$. The arbitrary nomenclature of the chromosomes was followed after Khuda-Bukhsh and Pal 1985, 1986a, b, Khuda-Bukhsh and Kar 1987, etc.

\section{Results and discussion}

The mitotic behaviour in all the 27 species under present study was essentially the same as described earlier for some other species of aphids in detail (Khuda-Bukhsh and Datta 1981, Khuda-Bukhsh and Pal 1984, 1985).

The typical diploid metaphase complements in the 27 species of aphids as listed in Table 1 have been represented in Figs. 1-27 and their respective idiograms in Figs. 28-54. The diploid number of chromosomes and their detailed morphometrical data of each species can be obtained from Table 2.

Cytological studies in aphids generally suffer from inherent difficulties because the sexual forms are not readily available and their occurrence is very much seasonal and restricted to some geographically or ecologically distinguished areas in India. Most of the aphid samples commonly available are parthenogenetically reproducing forms of females, for which chromosomal studies have mainly been restricted to their somatic tissues.

The diploid numbers of the hithertofore reported species of aphids are shown in Fig. 55 . 


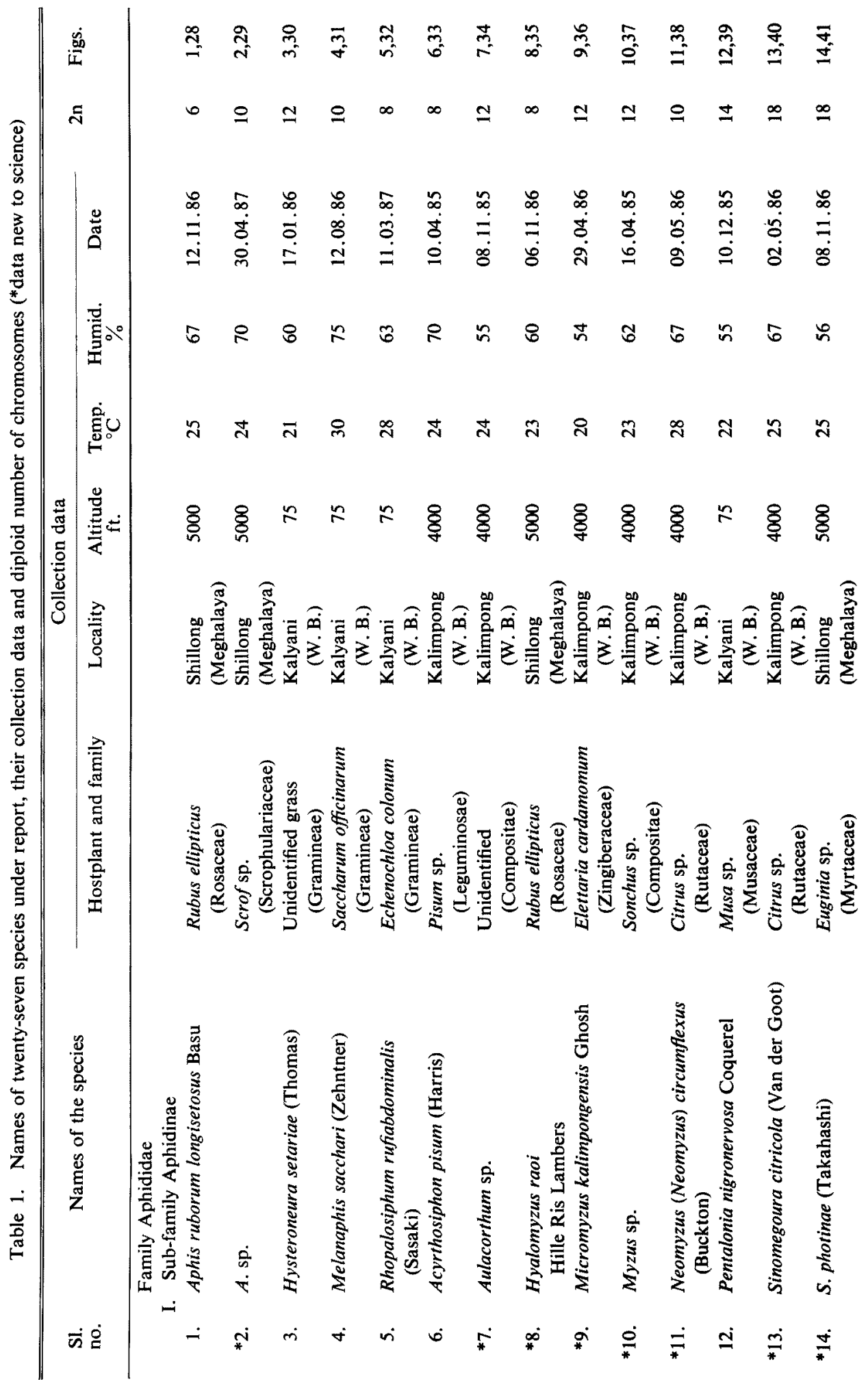




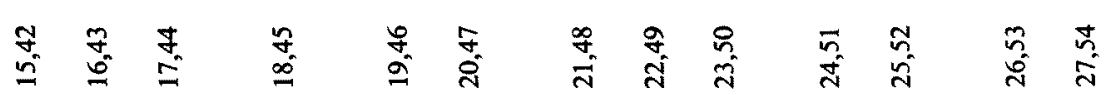

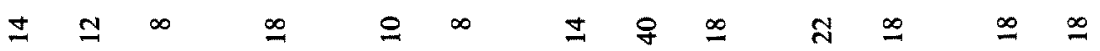

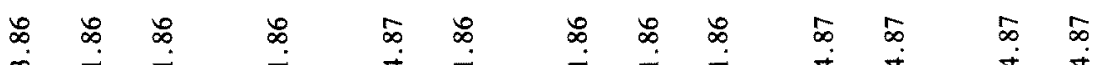

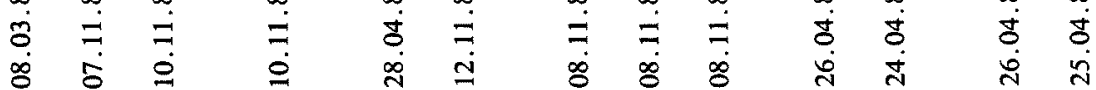

8 ช 8 ช 8 ช

辛

ఇ

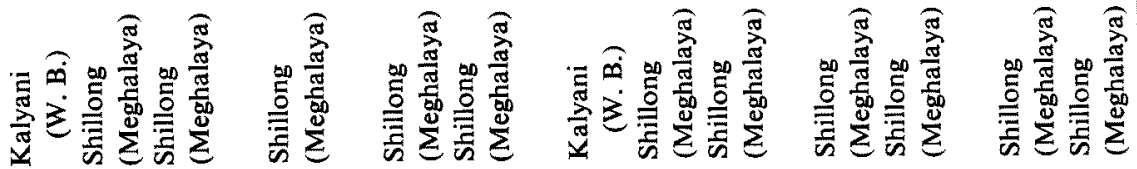

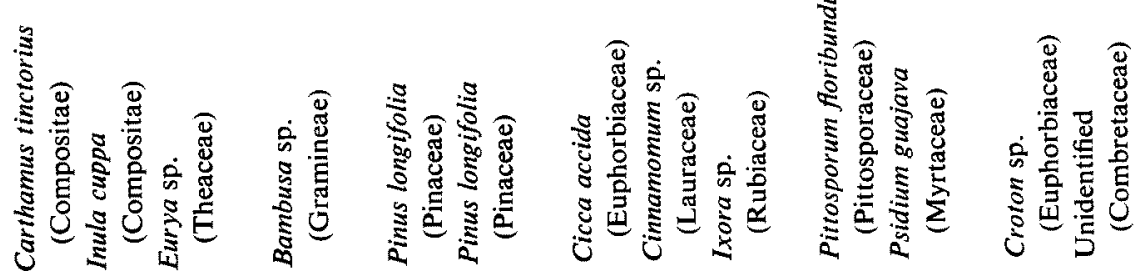

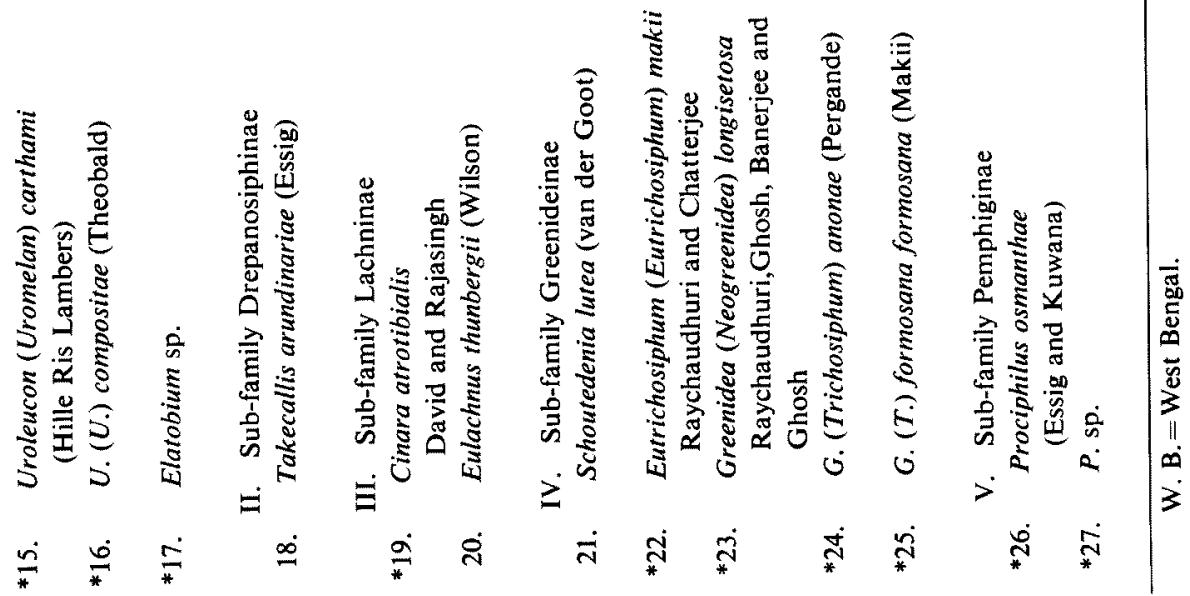


Table 2. Karyomorphometrical data of twenty-seven species under report

\begin{tabular}{|c|c|c|c|c|c|c|c|}
\hline \multirow{3}{*}{ Sl. no. } & \multirow{3}{*}{ Name of the species } & & & & & \multicolumn{2}{|c|}{ Chromosome } \\
\hline & & \multicolumn{2}{|c|}{1} & \multicolumn{2}{|c|}{2} & \multicolumn{2}{|c|}{3} \\
\hline & & $\mathrm{ml}(\mu \mathrm{m})$ & $\mathbf{R}_{\mathbf{L}}$ & $\mathrm{ml}(\mu \mathrm{m})$ & $\mathbf{R}_{\mathrm{E}}$ & $\mathrm{ml}(\mu \mathrm{m})$ & $\mathbf{R}_{\mathrm{L}}$ \\
\hline \multirow[t]{2}{*}{1.} & Aphis ruborum longisetosus & 7.80 & 39.77 & 6.66 & 33.96 & 5.15 & 26.26 \\
\hline & & $\mathrm{SE} \pm 0.29$ & L & 0.25 & $\mathbf{L}$ & 0.43 & $\mathbf{M}$ \\
\hline \multirow[t]{2}{*}{2.} & A. sp. & 5.20 & 28.80 & 4.68 & 25.92 & 4.18 & 23.15 \\
\hline & & $\mathrm{SE} \pm 0.95$ & M & 0.79 & $\mathbf{M}$ & 0.79 & $\mathbf{M}$ \\
\hline \multirow[t]{2}{*}{3.} & H. setariae & 6.41 & 26.38 & 4.52 & 18.60 & 3.79 & 15.60 \\
\hline & & $\mathrm{SE} \pm 0.46$ & $\mathbf{M}$ & 0.41 & $\mathbf{S}$ & 0.27 & $\mathbf{S}$ \\
\hline \multirow[t]{2}{*}{4.} & M. sacchari & 6.00 & 26.94 & 5.26 & 23.61 & 4.25 & 19.08 \\
\hline & & $\mathrm{SE} \pm 0.30$ & $\mathbf{M}$ & 0.37 & M & 0.31 & $\mathbf{S}$ \\
\hline \multirow[t]{2}{*}{5.} & R. rufiabdominalis & 5.45 & 30.60 & 4.95 & 25.26 & 4.41 & 24.76 \\
\hline & & $\mathrm{SE} \pm 0.62$ & L & 0.66 & $\mathbf{M}$ & 0.93 & $\mathbf{M}$ \\
\hline \multirow[t]{2}{*}{6.} & A. pisum & 6.70 & 34.01 & 6.20 & 31.47 & 4.50 & 22.84 \\
\hline & & $\mathrm{SE} \pm 0.31$ & L & 0.27 & $\mathbf{L}$ & 0.15 & $\mathbf{M}$ \\
\hline \multirow[t]{2}{*}{7.} & Aulacorthum sp. & 5.60 & 24.85 & 4.13 & 18.33 & 3.57 & 15.34 \\
\hline & & $\mathrm{SE} \pm 0.90$ & M & 0.74 & $\mathrm{~S}$ & 0.75 & $\mathbf{S}$ \\
\hline \multirow[t]{2}{*}{8.} & H. raoi & 5.94 & 31.59 & 4.76 & 25.31 & 4.30 & 22.87 \\
\hline & & $\mathrm{SE} \pm 0.74$ & L & 0.56 & M & 0.37 & $\mathbf{M}$ \\
\hline \multirow[t]{2}{*}{9.} & M. kalimpongensis & 4.60 & 24.94 & 3.83 & 20.77 & 3.12 & 16.91 \\
\hline & & $\mathrm{SE} \pm 0.77$ & M & 0.47 & M & 0.27 & $\mathbf{S}$ \\
\hline \multirow[t]{2}{*}{10.} & Myzus sp. & 6.70 & 24.00 & 5.98 & 21.42 & 5.30 & 18.93 \\
\hline & & $\mathrm{SE} \pm 0.65$ & M & 0.50 & $\mathbf{M}$ & 0.39 & $\mathbf{S}$ \\
\hline \multirow[t]{2}{*}{11.} & $N .(N$.$) circumflexus$ & 4.54 & 30.12 & 3.74 & 24.81 & 2.88 & 19.11 \\
\hline & & $\mathrm{SE} \pm 0.26$ & L & 0.43 & $\mathbf{M}$ & 0.29 & $\mathbf{S}$ \\
\hline \multirow[t]{2}{*}{12.} & $P$. nigronervosa & 6.46 & 28.78 & 3.66 & 16.31 & 3.19 & 14.21 \\
\hline & & $\mathrm{SE} \pm 0.56$ & $\mathbf{M}$ & 0.26 & $\mathbf{S}$ & 0.39 & $\mathbf{S}$ \\
\hline 13. & S. citricola & 6.02 & 26.57 & 2.97 & 13.12 & 2.48 & 10.94 \\
\hline & & $\mathrm{SE} \pm 0.54$ & $\mathbf{M}$ & 0.29 & $\mathbf{S}$ & 0.17 & $\mathbf{S}$ \\
\hline 14. & S. photinae & 5.10 & 21.30 & 3.12 & 13.03 & 2.81 & 11.73 \\
\hline & & $\mathrm{SE} \pm 0.97$ & M & 0.05 & S & 0.10 & $\mathbf{S}$ \\
\hline 15. & U. (U.) carthami & 8.12 & 24.83 & 6.00 & 18.35 & 5.35 & 16.36 \\
\hline & & $\mathrm{SE} \pm 0.64$ & M & 0.65 & S & 0.22 & $\mathrm{~S}$ \\
\hline 16. & $U .(U$.$) compositae$ & 7.75 & 27.90 & 6.00 & 21.60 & 5.12 & 18.43 \\
\hline & & $\mathrm{SE} \pm 0.92$ & $\mathbf{M}$ & 0.33 & $\mathbf{M}$ & 0.38 & $\mathbf{S}$ \\
\hline 17. & Elatobium sp. & 3.90 & 30.49 & 3.46 & 27.05 & 2.90 & 22.67 \\
\hline & & $\mathrm{SE} \pm 0.67$ & L & 0.81 & M & 0.63 & M \\
\hline 18. & T. arundinariae & 9.08 & 24.36 & 5.30 & 14.22 & 4.29 & 11.51 \\
\hline & & $\mathrm{SE} \pm 0.38$ & M & 0.58 & S & 0.53 & $\mathbf{S}$ \\
\hline 19. & C. atrotibialis & 11.04 & 33.80 & 6.50 & 19.90 & 5.58 & 17.08 \\
\hline & & $\mathrm{SE} \pm 0.97$ & L & 0.44 & $S$ & 0.26 & $S$ \\
\hline 20. & E. thunbergii & 11.50 & 34.52 & 8.50 & 25.51 & 7.65 & 22.96 \\
\hline & & $\mathrm{SE} \pm 0.65$ & $\mathbf{L}$ & 0.12 & M & 0.10 & $\mathbf{M}$ \\
\hline 21. & S. lutea & 6.40 & 23.90 & 4.88 & 18.22 & 3.80 & 14.19 \\
\hline & & $\mathrm{SE} \pm 0.82$ & M & 0.86 & $\mathbf{S}$ & 0.54 & $\mathbf{S}$ \\
\hline$* 22$ & E. (E.) makii & & & & & & \\
\hline 23. & $G .(N$.$) longisetosa$ & 4.94 & 15.56 & 4.40 & 13.86 & 3.99 & 12.57 \\
\hline & & $\mathrm{SE} \pm 0.10$ & $\mathbf{S}$ & 0.17 & $\mathbf{S}$ & 0.18 & S \\
\hline$* * 24$ & G. $(T$.$) anonae$ & & & & & & \\
\hline 25. & G. (T.) formosana & 8.57 & 19.16 & 6.25 & 13.97 & 5.24 & 11.71 \\
\hline & formosana & $\mathrm{SE} \pm \mathbf{0 . 5 1}$ & $\mathbf{S}$ & 0.82 & $\mathrm{~S}$ & 0.75 & $\mathbf{S}$ \\
\hline 26. & P. osmanthae & 10.10 & 34.74 & 3.61 & 12.41 & 2.67 & 9.18 \\
\hline & & $S E \pm 0.91$ & L & 0.62 & $\mathrm{~S}$ & 0.14 & VS \\
\hline 27. & $P . \mathrm{sp}$. & 7.12 & 22.61 & 4.58 & 14.54 & 3.70 & 11.75 \\
\hline & & $\mathrm{SE} \pm 0.97$ & M & 0.81 & S & 0.61 & $\mathrm{~s}$ \\
\hline
\end{tabular}


( ${ }^{*}$ data of $2=40$ and ${ }^{* *}$ data of $2 n=22$ given seperately below the Table)

\begin{tabular}{|c|c|c|c|c|c|c|c|c|c|c|c|}
\hline \multicolumn{12}{|c|}{ number (no.) } \\
\hline \multicolumn{2}{|c|}{4} & \multicolumn{2}{|c|}{5} & \multicolumn{2}{|l|}{6} & \multicolumn{2}{|l|}{7} & \multicolumn{2}{|l|}{8} & \multicolumn{2}{|l|}{9} \\
\hline $\mathrm{ml}(\mu \mathrm{m})$ & $\mathbf{R}_{\mathrm{L}}$ & $\mathrm{ml}(\mu \mathrm{m})$ & $\mathbf{R}_{\mathrm{L}}$ & $\mathrm{ml}(\mu \mathrm{m})$ & $\overline{\mathbf{R}_{\mathrm{L}}}$ & $\mathrm{ml}(\mu \mathrm{m}$ & $\mathrm{R}_{\mathrm{I}}$ & $\mathrm{ml}(\mu \mathrm{m}$ & $\overline{\mathbf{R}_{\mathrm{L}}}$ & $\mathrm{ml}(\mu \mathrm{m}$ & $\mathbf{R}_{\mathrm{L}}$ \\
\hline- & - & - & - & - & - & - & - & - & - & - & - \\
\hline 2.24 & 12.40 & 1.75 & 9.69 & - & - & - & - & - & - & - & - \\
\hline 0.29 & S & 0.23 & VS & & & & & & & & \\
\hline 3.53 & 14.53 & 3.19 & 13.13 & 2.85 & 11.73 & - & - & - & - & & \\
\hline 0.26 & $\mathbf{S}$ & 0.23 & $\mathbf{S}$ & 0.22 & $\mathbf{S}$ & & & & & & \\
\hline 3.75 & 16.83 & 3.01 & 13.51 & - & - & - & - & - & - & - & - \\
\hline 0.27 & S & 0.25 & S & & & & & & & & \\
\hline 3.00 & 16.84 & - & - & - & - & - & - & - & - & - & - \\
\hline 0.66 & $\mathrm{~S}$ & & & & & & & & & & \\
\hline 2.30 & 11.67 & - & - & - & - & - & - & - & - & - & - \\
\hline 0.09 & S & & & & & & & & & & \\
\hline 3.41 & 15.13 & 3.05 & 13.53 & 2.77 & 12.29 & - & - & - & - & - & - \\
\hline 0.69 & $\mathbf{S}$ & 0.54 & $\mathrm{~S}$ & 0.56 & $\mathbf{S}$ & & & & & & \\
\hline 3.80 & 20.21 & - & - & - & - & - & - & - & - & - & - \\
\hline 0.19 & $\mathbf{M}$ & & & & & & & & & & \\
\hline 2.65 & 14.37 & 2.39 & 12.96 & 1.85 & 10.03 & - & - & - & - & - & - \\
\hline 0.21 & S & 0.25 & $\mathbf{S}$ & 0.12 & $\mathbf{S}$ & & & & & & \\
\hline 4.54 & 16.26 & 2.99 & 10.71 & 2.40 & 8.59 & - & - & - & - & - & - \\
\hline 0.21 & $\mathbf{S}$ & 0.27 & $\mathbf{S}$ & 0.20 & Vs & & & & & & \\
\hline 2.09 & 13.86 & 1.82 & 12.34 & - & - & - & - & - & - & - & - \\
\hline 0.09 . & $\mathrm{S}$ & 0.10 & $\mathbf{S}$ & & & & & & & & \\
\hline 2.77 & 12.34 & 2.50 & 11.14 & 2.10 & 9.35 & 1.76 & 7.84 & - & - & - & - \\
\hline 0.11 & S & 0.14 & $\mathrm{~S}$ & 0.10 & VS & 0.07 & VS & & & & \\
\hline 2.15 & 9.49 & 2.00 & 8.83 & 1.90 & 8.38 & 1.86 & 8.21 & 1.73 & 7.63 & 1.54 & 6.79 \\
\hline 0.10 & VS & 0.06 & VS & 0.09 & VS & 0.08 & vS & 0.06 & VS & 0.03 & VS \\
\hline 2.55 & 10.65 & 2.36 & 9.85 & 2.19 & 9.14 & 2.05 & 8.56 & 1.95 & 8.14 & 1.81 & 7.56 \\
\hline 0.16 & S & 0.17 & VS & 0.12 & VS & 0.05 & VS & 0.08 & vS & 0.10 & VS \\
\hline 4.31 & 13.18 & 3.40 & 10.40 & 2.95 & 9.02 & 2.56 & 7.83 & - & - & - & - \\
\hline 0.84 & S & 0.52 & $\mathrm{~S}$ & 0.20 & VS & 0.36 & VS & & & & \\
\hline 4.08 & 14.69 & 2.65 & 9.54 & 2.17 & 7.81 & - & - & - & - & - & - \\
\hline 0.74 & S & 0.20 & VS & 0.13 & VS & & & & & & \\
\hline 2.53 & 19.78 & - & - & - & - & - & - & - & - & - & - \\
\hline 0.60 & S & & & & & & & & & & \\
\hline 3.75 & 10.06 & 3.35 & 8.98 & 3.21 & 8.61 & 2.95 & 7.91 & 2.79 & 7.48 & 2.55 & 6.84 \\
\hline 0.60 & $\mathbf{S}$ & 0.38 & VS & 0.37 & VS & 0.37 & vS & 0.29 & VS & 0.31 & VS \\
\hline 5.14 & 15.73 & 4.40 & 13.47 & - & - & - & - & - & - & - & - \\
\hline 0.28 & $\mathrm{~S}$ & 0.28 & $\mathbf{S}$ & & & & & & & & \\
\hline 5.66 & 16.99 & - & - & - & - & - & - & - & - & - & - \\
\hline 0.45 & S & & & & & & & & & & \\
\hline 3.60 & 13.44 & 3.14 & 11.72 & 2.59 & 9.67 & 2.36 & 8.81 & - & - & - & - \\
\hline 0.52 & S & 0.43 & $\mathrm{~S}$ & 0.23 & VS & 0.21 & VS & & & & \\
\hline 3.62 & 11.40 & 3.37 & 10.61 & 3.29 & 10.36 & 3.05 & 9.60 & 2.74 & 8.63 & 2.34 & 7.37 \\
\hline 0.11 & S & 0.13 & $\mathrm{~S}$ & 0.15 & $\mathrm{~S}$ & 0.02 & vS & 0.21 & vs & 0.20 & VS \\
\hline 4.86 & 10.86 & 4.51 & 10.08 & 4.23 & 9.45 & 3.90 & 8.72 & 3.79 & 8.47 & 3.37 & 7.53 \\
\hline 0.74 & S & 0.64 & S & 0.44 & VS & 0.44 & VS & 0.50 & VS & 0.45 & VS \\
\hline 2,45 & 8.42 & 2.25 & 7.73 & 2.17 & 7.46 & 2.02 & 6.94 & 1.94 & 6.67 & 1.86 & 6.39 \\
\hline 0.10 & vs & 0.16 & VS & 0.15 & VS & 0.06 & VS & 0.06 & vs & 0.09 & VS \\
\hline 3.12 & 9.91 & 2.91 & 9.24 & 2.85 & 9.05 & 2.60 & 8.25 & 2.44 & 7.75 & 2.16 & 6.86 \\
\hline 0.43 & VS & 0.47 & VS & 0.49 & VS & 0.38 & VS & 0.31 & VS & 0.23 & VS \\
\hline
\end{tabular}


Table 2.

\begin{tabular}{|c|c|c|c|c|c|c|c|}
\hline \multirow{3}{*}{ Sl. No. } & \multirow{3}{*}{ Name of the species } & & & & & \multicolumn{2}{|c|}{ Chromosome } \\
\hline & & \multicolumn{2}{|c|}{1} & \multicolumn{2}{|c|}{2} & \multicolumn{2}{|c|}{3} \\
\hline & & $\mathrm{ml}(\mu \mathrm{m})$ & $\mathbf{R}_{\mathbf{L}}$ & $\mathrm{ml}(\mu \mathrm{m})$ & $\mathbf{R}_{\mathrm{L}}$ & $\mathrm{ml}(\mu \mathrm{m})$ & $\mathbf{R}_{\mathbf{L}}$ \\
\hline \multirow[t]{8}{*}{$* 22$} & E. (E.) makii & 4.57 & 9.32 & 3.63 & 7.40 & 3.36 & 6.85 \\
\hline & & $\mathrm{SE}_{ \pm} 0.20$ & VS & 0.34 & vs & 0.28 & VS \\
\hline & Chro. no. & \multicolumn{2}{|c|}{10} & \multicolumn{2}{|c|}{11} & \multicolumn{2}{|c|}{12} \\
\hline & & 2.26 & 4.61 & 2.19 & 4.47 & 2.09 & 4.26 \\
\hline & & $\mathrm{SE} \pm 0.09$ & VS & 0.11 & VS & 0.09 & VS \\
\hline & Chro. no. & \multicolumn{2}{|l|}{19} & \multicolumn{2}{|c|}{20} & & \\
\hline & & 1.65 & 3.36 & 1.58 & 3.22 & & \\
\hline & & $\mathrm{SE} \pm 0.09$ & VS & 0.10 & VS & & \\
\hline \multirow[t]{5}{*}{$* * 24$} & G. (T.) anonae & 3.40 & 12.50 & 3.05 & 11.21 & 2.74 & 10.07 \\
\hline & & $\mathrm{SE} \pm 0.34$ & S & 0.31 & $S$ & 0.27 & $\mathbf{S}$ \\
\hline & Chro. no. & \multicolumn{2}{|l|}{10} & \multicolumn{2}{|l|}{11} & & \\
\hline & & 1.97 & 7.24 & 1.84 & 6.76 & & \\
\hline & & $\mathrm{SE} \pm 0.26$ & VS & 0.29 & vS & & \\
\hline
\end{tabular}

$\mathrm{ml}=$ mean length in micra; $\mathrm{R}_{\mathrm{L}}=$ relative percentage length; $\mathrm{SE}=$ standard Error; $\mathrm{L}=$ long; $\mathrm{S}=\mathrm{short}$;

The peak of diploid number lay on 12 . Thus, from the available data, the modal number in Aphididae seems to be $2 n=12$, which can only be verified and confirmed when more chromosome data in this group will be available. Shinji 1931 from an extensive study suggested $2 n=6$ as the primitive diploid number in aphids and opined that a gradual increase in number (due to fragmentation of chromosomes) had occurred during the evolution of each Sub-family, so that genera with the highest number could be regarded as most recent. However, Steffan $1968 \mathrm{a}, \mathrm{b}$ suggested that the general tendency has been towards a decreasing number (by fusion of chromosomes) rather than an increase. Sun and Robinson 1966 claimed $2 n=8$ as the primitive number of Aphididae. However, Blackman 1980 is more cautious to suggest that the primitive number could lay somewhere between 8 and 20 chromosomes. Thus, although the primitive karyotype in aphids is not yet firmly resolved, it may be concluded that repeated fragmentations and/or fusions of chromosomes in aphids (which are believed to be holokinetic in nature) played the key role in the karyotypic evolution in them.

In the Sub-family Aphidinae (Fig. 56), altogether 472 species have so far been cytologically investigated. The diploid numbers varied widely between 4 and 72 chromosomes with a distinct peak at 12 (represented by 161 species) followed by that of 8 (represented by 111 species) and 10 (represented by 71 species) chromosomes. Therefore, in this Sub-family the modal number seemed to be $2 \mathrm{n}=12$ chromosomes, from which the karyotypes with the other diploid numbers might have been derived.

In the Sub-family Drepanosiphinae (Fig. 57), the diploid numbers ranged between 6 and 48. $2 n=18$ chromosomes were encountered in 20 species, followed by $2 n=20$ and 14 chromosomes in 13 species and $2 n=16$ in 10 species. Therefore, from the available data, it is not possible to suggest any definite modal number for the Sub-family although peak apparently would point to $2 \mathrm{n}=18$.

In the Sub-family Lachninae (Fig. 58), the diploid numbers ranged between 8 and 38 chromosomes. The peak laid at $2 \mathrm{n}=10$ chromosomes although $2 \mathrm{n}=20$ and 18 chromosomes were also encountered in quite a good number of species. Thus, the modal number in this Sub-family is still obscure. Interestingly, Blackman 1980 reported a high incidence of structural heterozygosity in this group and it was suggested that there were some sibling species in this group yet to stabilize their karyotype in nature.

In the Sub-family Greeneidinae (Fig. 59), very limited works have been carried out and 
contd.

\begin{tabular}{|c|c|c|c|c|c|c|c|}
\hline \multicolumn{8}{|l|}{ number (no.) } \\
\hline 4 & \multicolumn{2}{|c|}{5} & \multicolumn{2}{|c|}{6} & 7 & 8 & \multirow{2}{*}{$\frac{9}{\mathrm{ml}(\mu \mathrm{m}) \quad \mathbf{R}_{\mathrm{L}}}$} \\
\hline $\mathrm{ml}(\mu \mathrm{m})$ & $\mathrm{ml}(\mu \mathrm{m})$ & $\mathbf{R}_{\mathrm{L}}$ & $\mathrm{ml}(\mu \mathrm{n}$ & $\mathbf{R}_{\mathbf{L}}$ & $\mathrm{ml}(\mu \mathrm{m}) \quad \mathbf{R}_{\mathrm{L}}$ & $\mathrm{ml}(\mu \mathrm{m})$ & \\
\hline $3.06 \quad 6.24$ & 2.92 & 5.96 & 2.80 & 5.71 & $2.60 \quad 5.30$ & $2.54 \quad 5.18$ & $2.36 \quad 4.81$ \\
\hline $0.24 \quad$ VS & 0.23 & VS & 0.17 & VS & 0.10 VS & 0.11 VS & 0.09 VS \\
\hline 13 & \multicolumn{2}{|c|}{14} & \multicolumn{2}{|c|}{15} & 16 & 17 & 18 \\
\hline $2.03 \quad 4.14$ & 1.98 & 4.04 & 1.94 & 3.95 & $1.87 \quad 3.81$ & 1.813 .69 & $1.75 \quad 3.57$ \\
\hline 0.05 & 0.05 & VS & 0.04 & VS & 0.07 & 0.10 & 0.09 \\
\hline
\end{tabular}

\begin{tabular}{lccccccccccc}
\hline 2.61 & 9.59 & 2.51 & 9.23 & 2.40 & 8.82 & 2.36 & 8.67 & 2.19 & 8.05 & 2.12 & 7.79 \\
0.22 & VS & 0.21 & VS & 0.26 & VS & 0.22 & VS & 0.25 & VS & 0.21 & VS
\end{tabular}

$\mathrm{VS}=$ very short; $\mathbf{M}=$ medium.

no clear-cut mode can be suggested. The diploid numbers widely varied between 7 and 40 .

In the Sub-family Pemphiginae (Fig. 60), the diploid numbers ranged between 8 and 38 . $2 n=10$ was observed in 20 species, $2 n=14$ in 14 species and $2 n=18$ in 12 species. Thus, this Subfamily also appeared to comprise cytologically heterogeneous assemblage of members. Many members of this Sub-family are gall-forming aphids, some of which produce true galls, while others produce pseudo-galls on leaf margins. No cytological characterization was, however, possible in respect of their gall-forming habit as reflected in their karyotypes which could be distinguished from non-gall forming ones (Khuda-Bukhsh 1980, Khuda-Bukhsh and Pal 1983, Pal and Khuda-Bukhsh 1983).

In the absence of primary constriction in the chromosomes of aphids, the karyomorphometrical data assume special significance in drawing up karyo-evolutionary relationships among different groups of aphids, particularly in those having the same diploid number. But much caution is needed in view of the intra-specific variations occasionally encountered while dealing with some polyphagous species, either from different natural populations or from different hostplants (Kar and Khuda-Bukhsh 1989). Thus, accurate ascertainment of karyotype of a given species is difficult and this devalues to a considerable extent an attempt to correlate groups of aphids depending solely on chromosomal data. However, the karyological data can be of additional help in certain cases, particularly the disputed ones, if critically analyzed along with data from other disciplines. Clearly, there is much scope for further refinement of techniques, particularly the $G$-banding, which could throw some more light on karyo-evolutionary inter-relationships among different groups of aphids.

\section{Summary}

The somatic karyotypes of twenty-seven species of aphids belonging to 5 Sub-families have been described. The majority of the aphid species were collected from various hostplants in different regions of the North-Eastern India and a few of them from the North-West India. An attempt has been made to evaluate the present state of karyotypic knowledge and the karyoevolutionary trend in these five Sub-families of Aphididae. 


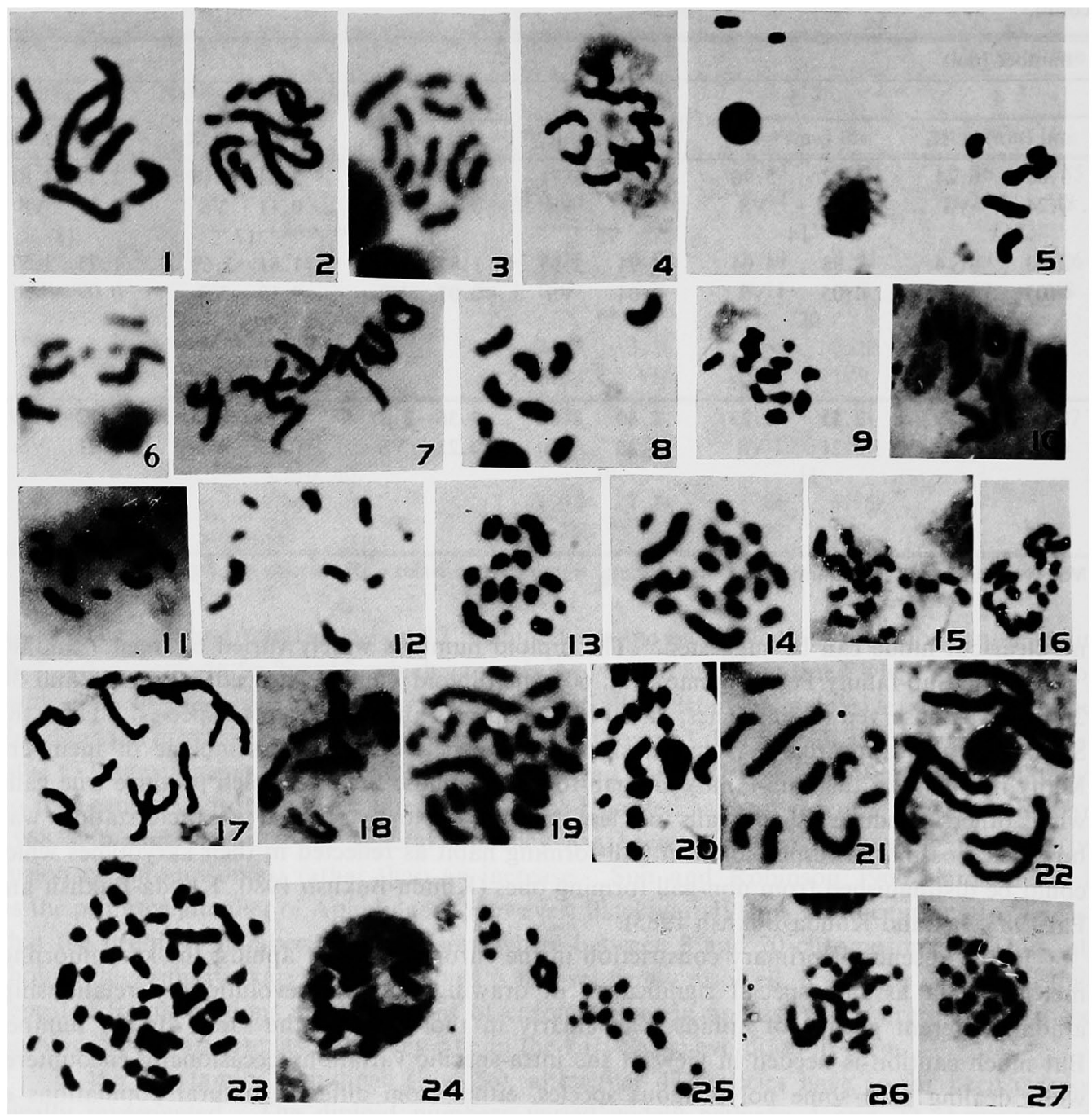

Figs. 1-27. Photomicrographs of metaphase spreads in embryonic cells of twenty-seven species of aphids as serialized in Table 1.

\section{Acknowledgments}

The authors are grateful to Prof. G. K. Manna and the Head, Department of Zoology, Kalyani University for encouragements and laboratory facilities; to the CSIR, Government of India, New Delhi for the financial support of the work; to Dr. M. R. Ghosh of Dept. of Entomology, V. C. K. V, Kalyani; to Dr. D. Raychaudhuri of Calcutta University and to Dr. R. L. Blackman of British Natural History Museum, London for their helps in identification of the aphid specimens; and to Dr. A. K. Sarkar of Botany Department, Kalyani University for his help in identification of the plant samples.

\section{References}

Blackman, R. L. 1980. Chromosome numbers in the Aphididae and their taxonomic significance. Syst. Ent. 5: 7-25. 

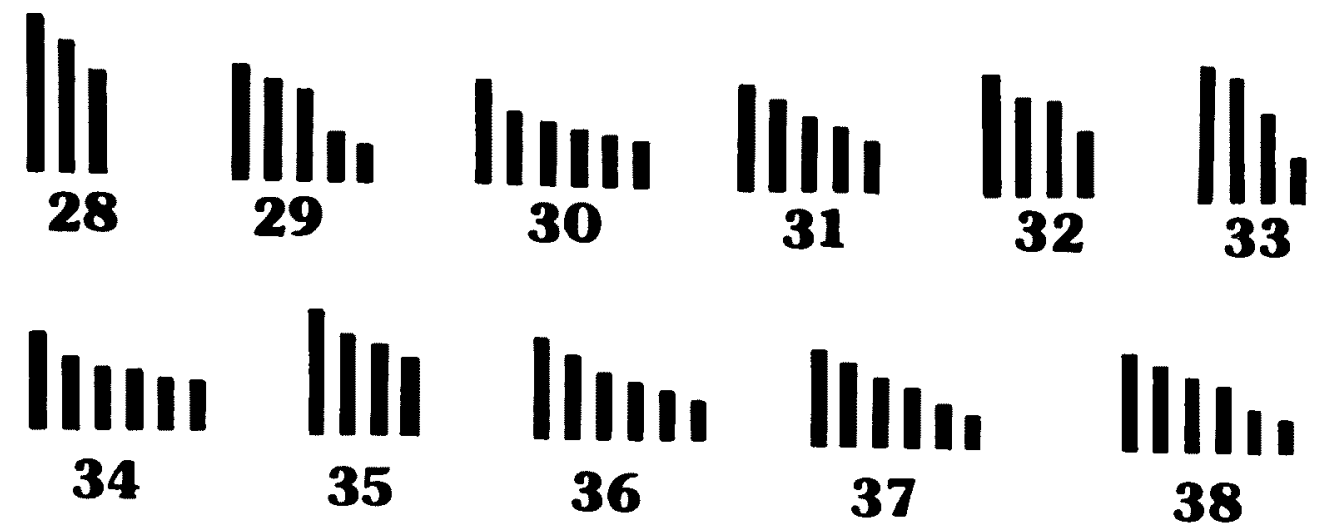

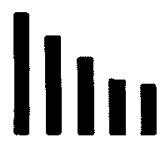

39

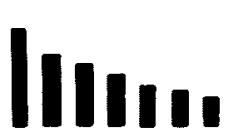
43

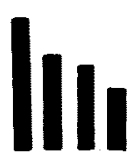

48

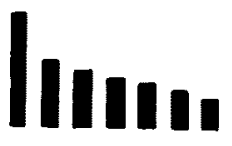

40

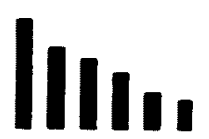

4.4

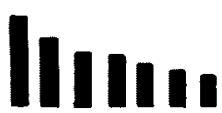

49

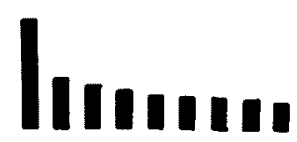

41

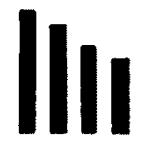

45

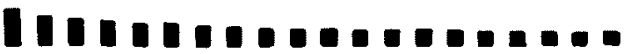 50}

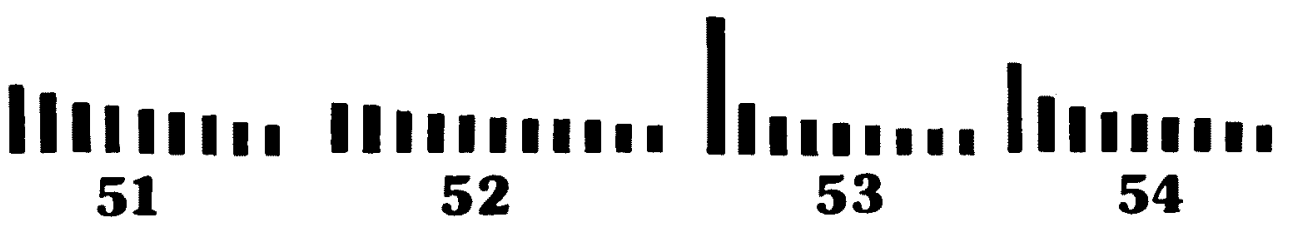

Figs. 28-54. Idiograms based on $\mathrm{R}_{\mathrm{L}}$ of chromosomes in the twenty-seven species of aphids as serialized and indicated in Tables 1 and 2.

Dixon, A. F. G. 1985. Aphid Ecology. Blackie and Sons Ltd. Bishopbrigg, Glasgow, G 64, 2NZ: 1-157.

Ghosh, A. K. 1975. A list of aphids (Homoptera: Aphididae) from India and adjacent countries. J. Bombay Nat. Hist. Soc. 71: 201-220.

Kar, I. and Khuda-Bukhsh, A. R. 1989. Intra-specific karyotypic variations in two species of polyphagous aphids (Homoptera: Aphididae). Entomon (Communicated).

-, Basu, G. and Khuda-Bukhsh, A. R. 1990. A check-list of chromosomes in aphids (Homoptera: Aphididae) worked out in India along with the names and families of their hostplants. Environ. and Ecol. 8: $414-428$.

Khuda-Bukhsh, A. R. 1980. Karyotypic studies in six species of aphids (Homoptera: Aphididae) from the Garhwal Himalayas (India). Entomon. 5(4): 247-250. 

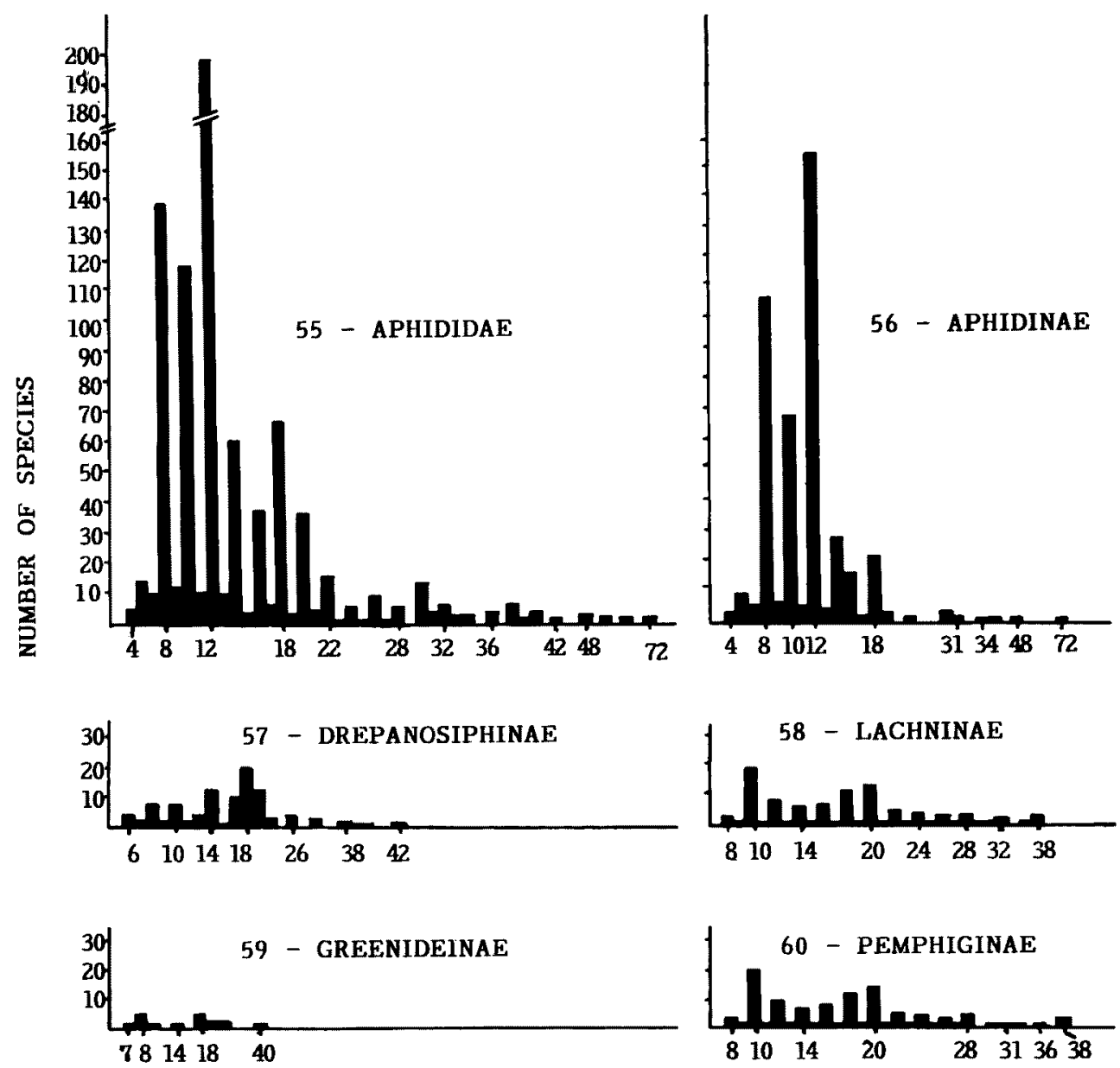

DIPLOID NUMBERS OF CHROMOSOMES

Figs. 55-60. Histograms showing distribution of diploid numbers in the family Aphididae (Fig. 55) and the Sub-families Aphidinae (Fig. 56), Drepanosiphinae (Fig. 57), Lachninae (Fig. 58), Greenideinae (Fig. 59) and Pemphiginae (Fig. 60).

- and Basu, G. 1987. Karyotypic studies on five species of aphids (Homoptera: Aphididae) from the North-Eastern Himalayas. Entomon. 12: 273-277.

- and Dutta, S. 1981. A preliminary note on the mitotic chromosome aberrations in embryos of whole-body X-irradiated parthenogenetic viviparous Aphis gossypii (Homoptera: Aphidiae). Chrom. Inf. Serv. 30: $4-5$.

- and Kar, I. 1987. Karyological studies in five species of Hormaphidine aphids (Homoptera: Aphididae). Entomon. 12(3): 267-271.

- and Pal, N. B. 1983. Karyology of four species of Gall-forming aphids (Homoptera: Aphididae) from the Garhwal Himalayas. Entomon. 2(8): 109-114.

- and - 1984. A further cytological investigation on Lipaphis erysimi (Homoptera: Aphididae): Chromosomal variations. In. Pers. in Cytol. and Genet. (Eds. G. K. Manna and U. Sinha), All India Congress of Cytology and Genetics Publication 4: 403-409.

- and -. 1985. Cytogenetical studies on aphids (Homoptera: Aphididae) from India I. Karyomorphology of eight species of Aphis. Entomon. 10(2): 171-177.

- and -. 1986a. Cytogenetical studies on aphids (Homoptera: Aphididae) from India II. Karyomorphology of five species of Myzus. Entomon. 11(2): 135-140. 
- and - 1986b. Cytogenetical studies on aphids (Homoptera: Aphididae) from India III. Karyomorphology of fifteen species belonging to the tribe Macrosiphini. Entomon. 11(2): 141-147.

Kurl, S. P. 1986. Chromosome numbers in aphids (Homoptera: Aphididae) of the world fauna. Proc. 2nd Nat. Symp. on Recent Trends in Aphidological Studies, Modinagar (Ed. S. P. Kurl), pp. 119-165.

Kuznetsova, V. G. and Shaposhnikov, G. H. 1973. Chromosome numbers of aphids (Homoptera: Aphididae) of the world fauna. (In Russian). Ent. Obozr. 52: 116-135.

Pal, N. B. and Khuda-Bukhsh, A. R. 1983. Chromosomal affinity in four species of Gall-forming aphids from Garhwal Himalayas. Environ. and Ecol, 1 : 97-99.

Sarkar, S. K. and Raychaudhuri, D. 1985. An account of aphid-aphidiid complex of Mizoram, North-east India. 2nd Nat. Symp. on Recent Trends in Aphidological Studies, Modinagar, Abs. No. 10, pp. 10.

Shinji, O. 1931. The evolutional significance of the chromosomes of the Aphididae. J. Morph. $51: 373-433$.

Steffan, A. W. 1968a. Zur Karyologie und Chromosomen-Evolution der Blattlause (Homoptera: Aphidina). Verhandlungen der Deutschen Zoologischen Gesellschaft. 1968: 558-575.

- 1968b. Evolution und Systematik der Adelgidae (Homoptera: Aphidina). Eine Verwandtschftsanalyse auf vorwiegend ethologischer, zytologischer und karyologischer Grundlage. Zoologica Stuttgart. 115: 1-139.

Sun, R. Y. and Robinson, A. G. 1966. Chromosome studies on fifty species of aphids. Can. J. Zool. 44: 649658. 